\title{
A new report of Moina macrocopa (Straus, 1820) (Cladocera, Anomopoda) in South America
}

\author{
Elmoor-Loureiro, LMA. ${ }^{\mathrm{a} *}$, Santangelo, JM. ${ }^{\mathrm{b} *}$, Lopes, PM. ${ }^{\mathrm{b} *}$ and Bozelli, RL. ${ }^{\mathrm{b} *}$ \\ aLaboratório de Zoologia, Universidade Católica de Brasília - UCB \\ QS 7 lote 1, Bloco M, sala 331, CEP 71966-700, Taguatinga, DF, Brazil \\ bLaboratório de Limnologia, Universidade Federal do Rio de Janeiro - UFRJ, \\ Av. Carlos Chagas Filho, 373, Prédio CCS subsolo, \\ sala A0-008, Ilha do Fundão, CEP 21941-590, Rio de Janeiro, RJ, Brazil \\ *e-mail: lourdes@ucb.br, jaymems@biologia.ufrj.br, paloma_unirio@yahoo.com.br, bozelli@biologia.ufrj.br \\ Received March 11, 2009 - Accepted March 24, 2009 - Distributed February 28, 2010
}

(With 10 figures)

In relevant reviews on the Moinidae, Goulden (1968) and Smirnov (1976) discussed the distribution of Moina macrocopa (Straus, 1820), showing that the typical form was distributed through the Old World, while Moina macrocopa americana Goulden, 1968 occurred in North America. These authors also pointed out that this species was absent in Central and South America.

However, in the last two decades, M. macrocopa has been reported from Bolivia (Elias-Gutierrez and Zamuriano-Claros, 1994) and Argentina (Paggi, 1997). In both cases, the specimens' features matched those of the typical form, instead of $M$. macrocopa americana. Although not discarding the possibility that South American populations could belong to a new subspecies, these authors argued for the possible introduction of M. macrocopa in South America from the Old World.

The present paper reports the occurrence of M. macrocopa sampled from a temporary pond, located in downtown Rio de Janeiro city (22'53 ${ }^{\circ} \mathrm{S}$ and $43^{\prime} 11^{\circ} \mathrm{W}$ ) in February 2008. The pond was located above a blocked rainwater drain and was completely dried up in the following month. Samples were collected using a $500 \mathrm{~mL}$ plastic bottle and were brought immediately to the laboratory, where some specimens were kept alive and others were separated and fixed immediately with $4 \%$ formalin.

The voucher specimens were deposited in the laboratory of limnology collection at the Universidade Federal do Rio de Janeiro and the zoology laboratory collection at the Universidade Católica de Brasília.

The Brazilian specimen features agree with those of the typical form (Figures 1-10): head and carapace surface covered with long hairs; head broad and without supraocular depression; antennule and antenna densely ciliated; anterior seta on the penultimate segment of the female's first trunk limb toothed; postabdomen with seven to ten lateral feathered teeth and one short bident tooth; ephippium with two eggs, and covered with brown polygonal cells; males hairy, with bent antennules, first trunk limb with large hook on the endopodite and long seta on the exopodite. Body lengths of parthenogenetic females ranged from 880 to $1088 \mu \mathrm{m}(\mathrm{n}=12)$, sexual females from 928 to $1024 \mu \mathrm{m}(\mathrm{n}=10)$, and males from 656 to $768 \mu \mathrm{m}(\mathrm{n}=6)$.

According to Goulden (1968), M. macrocopa presents 55 to 65 large setae on ventral margin of the carapace. Nevertheless, the observed specimens have about 75 setae, similar to the Argentine specimens, which presented 73 to 76 setae (Paggi, 1997). The Bolivian specimens, however, have only 45 to 56 setae (Elias-Gutierrez and Zamuriano-Claros, 1994).

In the observed specimens, the cells in ephippium are superficial and flattened as in M. macrocopa americana, not deep as described for Old World and Argentine populations (Goulden, 1968; Paggi, 1997).

In brief, comparing to the description of Old World populations, the South American M. macrocopa show differences on the number of carapace ventral setae and the ephippium surface. Nevertheless, these features are not consistent in all known South American populations, and, therefore, do not support the hypothesis that they were indigenous and could represent a different subspecies. Certainly, a more detailed comparison among populations from different continents is necessary to better evaluate this hypothesis.

At least from the 1980's, M. macrocopa macrocopa has been cultured for aquaculture and bioassays purpose in Peru (Valdivia-Villar, 1988), Argentina (Paggi, 1997) and Chile (Iannacone and Alvariño, 2002). Thus, the introduction of this taxon in South American water bodies is an actual possibility.

If the occurrence of M. macrocopa in South America really resulted from invasion, we could infer that the dispersion in South America is going fast. This taxon was sampled for the first time in 1992 in Bolivia (Elias-Gutierrez and Zamuriano-Claros, 1994), and after 16 years it is already present in three different hydrological basins.

The occurrence of $M$. macrocopa in an ephemeral pool was previously reported (Paggi, 1997). In Bolivia, it was found in Laguna Albarrancho (Elias-Gutierrez and Zamuriano-Claros, 1994). Taking these and the records presented by Goulden (1968) into consideration, it seems that M. macrocopa occurs preferentially in small water bodies. 

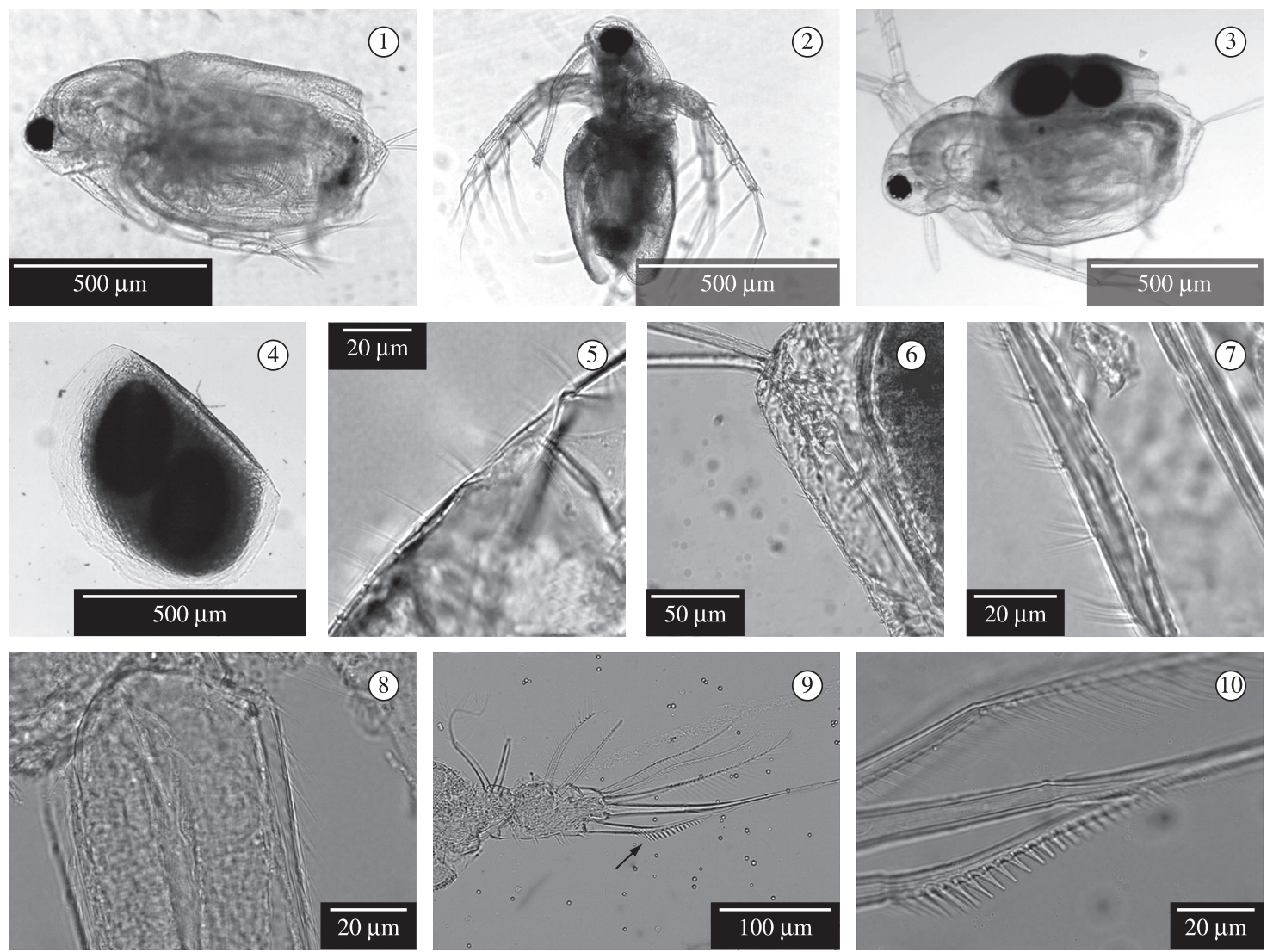

Figures 1-10. Moina macrocopa from a temporary pool in Rio de Janeiro city. 1) parthenogenetic female; 2) male; 3) sexual female; 4) ephippium; 5) carapace surface, with "hairs"; 6-7) dorsal margin of the postabdomen; 8) basal segment of antenna ramus; 9) first trunk limb (arrow indicates the toothed setae of the penultimate segment); 10. toothed seta of first trunk limb and two terminal seta.

\section{References}

ELIAS-GUTIERREZ, M. and ZAMURIANO-CLAROS, R., 1994. Primer registro de Moina macrocopa (Daphhniiformes: Moinidae) en Bolivia. Revista de Biología, vol. 42, no. 1/2, p. 385 .

GOULDEN, CE. The systematics and evolution of the Moinidae., 1968. Transactions of American Philosophical Society, vol. 58, no. 6, p. 1-101.

IANNACONE, J. and ALVARIÑO, L., 2002. Evaluación del riesgo ambiental del insecticida Cartap en bioensayos con tres invertebrados. Agricultura Tecnica, vol. 62, no. 3, p. $366-374$.

PAGGI, JC., 1997. Moina Macrocopa (Straus, 1820) (Branchiopoda, Anomopoda) in South America: another case of species introduction? Crustaceana, vol. 70, no. 8, p. 886-893.

SMIRNOV, NN., 1976. Macrothricidae I Moinidae fauni mira. Fauna SSSR. Rakoobraznie, vol. 1, no. 3, p. 1-237. [Macrothricidae and Moinidae of the world . In Russian]. 